\title{
Comparative Analysis Between Cellular Oncogenes and Viral Oncogenes
}

\author{
Adina-Gabriela Puiu ${ }^{1, \dagger}$, Oana Grigoraș ${ }^{1, \dagger}$, Maria-Irina Preda ${ }^{1, \dagger}$, Marian Constantin ${ }^{1}$, Andrei-Mihai \\ Vasilescu ${ }^{1, \dagger}, *$
}

1 Department of Genetics, Faculty of Biology, University of Bucharest, Bucharest, Romania; adinapuiu1996@ gmail.com (A.G.P.); grigoras.oana95@gmail.com (O.G.); mariairinapreda28@gmail.com (M.I.P.); andrei.vasilescu10@gmail.com (A.M.V.);

* Correspondence: andrei.vasilescu10@gmail.com;

$\dagger \quad$ These authors contributed equally to this work;

Received: 24.08.2020; Revised: 14.09.2020; Accepted: 15.09.2020; Published: 23.09.2020

\begin{abstract}
Carcinogenesis is a complex process that consists of multiple genetic events, leading to the activation of dominant-acting oncogenes and the cancellation of certain tumor suppressor genes functions. Previous studies on interactions between oncogenes and cells proved that viral or cellular oncogenes have a determinant role in malignant cells by supporting aberrant proliferation, epigenetic alterations, and reprogramming. After the cellular differentiation is complete, tumor suppressor genes are involved in cell regulation, by inhibiting mitogenic signaling pathways and cell cycle progression and by keeping the stability of the genome. Mutations that lead to loss of TSG function are commonly identified in various cancer types, such as lung, cervical, breast, pancreatic and colorectal cancer. The aim of this study is to specify the genetic factors involved in tumor and malignant processes and to compare the oncogene types in order to establish an evolutionary correlation between them. The analysis of cellular and viral oncogenes shows that their structure and functions are alike, which supports the idea that viral oncogenes originated from cell proto-oncogenes. This is an intensively studied field with high hopes of better understanding carcinogenesis and discovering novel therapies based on the genetic modifications that occur in malignant cells.
\end{abstract}

Keywords: carcinogenesis; cervical cancer; evolution; lung cancer; oncogene; proto-oncogene; TSG; virus.

() 2020 by the authors. This article is an open-access article distributed under the terms and conditions of the Creative Commons Attribution (CC BY) license (https://creativecommons.org/licenses/by/4.0/).

\section{Introduction}

Cancers are heterogeneous diseases characterized by genetic instability and alteration of DNA reparatory function, which leads to cell cycle deregulation and uncontrolled proliferation, dedifferentiation, and cellular immortalization. The cancer cell generates malignant clones that can invade adjacent tissue and subsequently metastasize. Malignant transformation is determined by a series of external (physical, biological, and chemical mutagenic agents) and internal (proto-oncogenes and tumor suppressor gene mutations) factors $[1,2]$.

Oncogenic virus studies lead to the discovery of viral oncogenes, which represent a hallmark for the discovery of the molecular mechanisms involved in malignant transformation. Subsequent analysis of viral oncogenes leads to the identification of cellular oncogenes, which are responsible for non-viral cancers [3]. 
Proto-oncogenes play an essential role in normal cell proliferation and development. Their transcription is controlled by tumor suppressor genes (TSG) and by epigenetic factors. If subjected to mutations or abnormal epigenetic control, proto-oncogenes can be improperly expressed, leading to cell malignancy [2].

Oncogenes were first discovered in retroviruses (viruses with RNA genomes), and they were identified as malignant agents in various animal species. In the mid-'70's, American microbiologists John Michael Bishop and Harold Varmus tested the theory that healthy cells have latent viral oncogenes that determine cancers when activated. They proved that oncogenes originate from normal genes (proto-oncogenes) that naturally exist in the cells of organisms [4].

\section{Proto-oncogenes}

The proto-oncogene group modulates the cell cycle; in most cases, their expression products being involved in cellular division, growth, differentiation, and apoptosis inhibition. These functions make them essential for embryogenesis and tissue regeneration. Protooncogenes are partially or even completely silenced after cellular differentiation is complete. When they suffer alterations (e.g., mutations or epigenetic modifications), which are able to completely reactivate them, the proto-oncogenes become oncogenes, and, if overexpressed, they lead to abnormal cell proliferation, dedifferentiation, and immortality, turning them to malignant tumoral cells (Table 1) [5,6,7,8].

Table 1. The main proto-oncogenes (based on Cooper, 2000).

\begin{tabular}{l|l|l} 
Proto-oncogene & Type of cancer & Activating mutation \\
\hline$a b l$ & $\begin{array}{l}\text { Acute lymphocytic leukemia, chronic myelogenous } \\
\text { leukemia }\end{array}$ & Translocation \\
\hline$a k t$ & Pancreatic and ovarian cancer & Amplification \\
\hline$b c l-2$ & Follicular B-cell lymphoma & Translocation \\
\hline$D 1$ & B-cell lymphoma, parathyroid adenoma & Translocation \\
\hline$D 1$ & $\begin{array}{l}\text { Esophageal, liver, lung, breast, squamous cell, bladder } \\
\text { carcinomas }\end{array}$ & Amplification \\
\hline$E 2 A / p b x 1$ & Acute lymphocytic leukemia & Translocation \\
\hline erbB-2 & Ovarian and breast cancer & Amplification \\
\hline$g i p$ & Ovarian and adrenal cortical cancer & Point mutation \\
\hline$g l i$ & Glioblastoma & Amplification \\
\hline$g s p$ & Thyroid and pituitary cancer & Point mutation \\
\hline$h o x-11$ & Acute T-cell leukemia & Translocation \\
\hline$l y l$ & Acute T-cell leukemia & Translocation \\
\hline c-myc & Burkitt's lymphoma & Translocation \\
\hline $\mathrm{L}-m y c$ & Lung and breast cancer & Amplification \\
\hline $\mathrm{N}-m y c$ & Lung cancer & Amplification \\
\hline$P D G F R$ & Lung cancer, neuroblastoma & Amplification \\
\hline$E G F R$ & Chronic myelomonocytic leukemia & Translocation \\
\hline$H r a s$ & Lung cancer & Translocation \\
\hline Kras & Thyroid cancer & Point mutation \\
\hline$N r a s$ & Thyroid, lung, pancreatic and colon cancer & Point mutation \\
\hline$r e t$ & $\begin{array}{l}\text { Thyroid cancer, acute myelogenous and lymphocytic } \\
\text { leukemias }\end{array}$ & Point mutation \\
\hline$r e t$ & Type 2A and 2B endocrine neoplasia & Point mutation \\
\hline$S M O$ & Thyroid cancer & Chromosomal rearrangement \\
\hline Basal cell carcinoma & Point mutation
\end{tabular}

The most studied family of proto-oncogenes is ras, which includes the Hras, Kras, and Nras genes. These genes code for $\mathrm{G}$ proteins, which activate a cascade of protein kinase reactions, followed by the activation of nuclear transcription factors and altered gene expression [9]. Also, the Kras gene is activated in 30\%-40\% cancer cases and is associated 
with neoplastic progression. The HER2/neu proto-oncogene is correlated with severe forms of ovarian and breast cancer and is overexpressed in one-third of pulmonary adenocarcinomas with poor prognosis [10].

The $c$-myc proto-oncogene (8q24.21) codes for a nuclear phosphoprotein, which regulates gene transcription by inducing or repressing expression. The activity of this gene is controlled by the APC (Adenomatosis Polyposis Coli) tumor suppressor gene, whose product blocks the binding of $\beta$-catenin to Tcf-4 (T cell factor-4), and then inhibiting the expression of $c$-myc. If $A P C$ is mutated, $c-m y c$ is expressed and stimulates cell proliferation, leading to neoplastic growth. The $c-m y c$ gene is often amplified in pulmonary tumors [10].

\section{Cellular oncogenes}

Approximately $80 \%$ of human cancers are linked to the action of physical and chemical mutagens, which produce mutations, epigenetic modifications, various errors in DNA repair and replication, and furthermore, cell cycle destabilizations [11]. In certain cases, these events lead to cellular proto-oncogene reactivation, which turns into oncogenes, sustaining the tumoral processes $[12,13]$.

In the COSMIC Cancer Gene Census project, Sondka et al. [13] compiled the statistics of all the previously reported and analyzed genes involved in malignant transformation in humans, and the results revealed 554 oncogenes and/or TSGs (tumor suppressor genes), which represent almost $2 \%$ of all the genes in the human genome [14]. This finding shows that many genes are involved in embryogenesis and development and that if these genes are mutated, they can lead to cell transformation. 72 genes of the 554 can function both as oncogenes and as TSGs, depending on the tissue where they are expressed and on the type of mutation that affects them.

\subsection{Mechanisms of cellular oncogene activation.}

Oncogenes can be activated by various mutagenic factors, of extracellular (radiation, carcinogenic chemical agents), or intracellular origin (free radicals, resulted from cellular oxidations, chronic inflammation, certain growth factors, hormones, or cytokines), or by the erroneous activity of cell mechanisms that protect it against genome destabilization (errors in DNA replication, or repair, deactivation of cell cycle checkpoints, the abolishment of apoptosis, deregulation of the immune system) $[15,16]$.

Oncogene activation can occur through a variety of mutations (missense/nonsense substitutions, deletions, insertions), but the most common are translocations. A sequence from a TSG, or from a proto-oncogene (or the entire gene) can be translocated adjacent to another gene or even inside it, resulting in a fusion gene. The fusion can be: a) between a protooncogene and a tumor suppressor gene; in this case, the proto-oncogene becomes overexpressed, and the tumor suppressor gene is inactivated; $b$ ) between a proto-oncogene and another gene that activates the former through its promoter, or enhancer; c) between a protooncogene and another gene that inactivates the autoinhibitory domain of the former gene, leading to the activation of the oncogene [13].

Oncogenes can also be activated through epigenetic alterations. These alterations at a global level in a cell represent an important marker for cancer. The main epigenetic modifications leading to cell transformation are abnormal DNA methylation/demethylation, histone modifications, and changes in the function of $\mu$ RNA molecules [17]. 
Essentially, every cell has a specific and tightly controlled epigenetic pattern according to the cell type, the tissue it belongs to, and the organism's development stage. This is so that only the right genes are expressed at a specific place and time. If enough modifications of the normal pattern accumulate, the transformation of the cell can occur. For example, protooncogenes are inactivated through extensive promoter methylation, whereas the hypomethylated tumor suppressor genes are still active. In the reverse situation, a protooncogene is demethylated and activated, and conversely, a tumor suppressor gene is inactivated through excessive methylation, leading to cell malignancy $[17,18]$.

\subsection{Cell cycle alteration mechanisms.}

Pulmonary carcinoma can initiate through the alteration of numerous proto-oncogenes involved in cell cycle regulation, especially EGFR and Kras. Mutations in these genes are transmitted in an autosomal dominant pattern, and they lead to an increased risk of developing hereditary pulmonary cancer $[12,19]$.

EGFR (Epidermal Growth Factor Receptor) is a transmembrane glycoprotein receptor. This receptor has a cytoplasmic tyrosine kinase domain, from which the intracellular signal transduction is realized through the Ras or through other pathways. The signal transmitted by these receptors can be upregulated by increasing the receptor molecules in the cell membrane (caused by gene amplification), or by continuous auto-phosphorylation of the tyrosine kinase domain (caused by EGFR overexpression, controlled by a strong promoter). This increase in cell signaling leads to a deregulation of the cell cycle, followed by aberrant proliferation. These mechanisms have been described in cases of non-small cell lung cancer [20,21].

\section{Tumor suppressor genes (TSG)}

Another phenomenon that leads to genetic alterations causing carcinogenesis is tumor suppressor gene mutations [22] (Table 2). Tumor suppressor genes play an essential role in inhibiting cell proliferation. Knudson [23] proposed the hypothesis that, in order for phenotypic modifications to occur, both alleles must be mutated, anticipating the haploinsufficiency phenomenon later described by Fang et al. [24].

Table 2. The main tumor suppressor genes (based on Cooper, 2000).

\begin{tabular}{l|l} 
TSG & Type of cancer \\
\hline$A P C$ & Colorectal cancer \\
\hline$B R C A 1$ & Breast and ovarian cancer \\
\hline$B R C A 2$ & Breast cancer \\
\hline$D P C 4$ & Pancreatic cancer \\
\hline$I N K 4$ & Brain tumors, lung cancer, melanoma, leukemias, lymphomas \\
\hline$M A D R 2$ & Colorectal cancer \\
\hline$N F 1$ & Neurofibrosarcoma \\
\hline$N F 2$ & Meningioma \\
\hline$T P 53$ & Brain tumors; esophageal, liver, lung, breast and colorectal cancer, leukemias, lymphomas, sarcomas \\
\hline$P T C$ & Basal cell carcinoma \\
\hline$P T E N$ & Brain tumors; lung, kidney, prostate, and endometrial cancer, melanoma \\
\hline$R b$ & Retinoblastoma, lung, breast, and bladder cancer, sarcomas \\
\hline$V H L$ & Renal cell carcinoma \\
\hline$W T 1$ & Wilms' tumor
\end{tabular}

The most common TSG mutation in TP53 (17p13.1) causes its inactivation and is detected in multiple types of cancer (including colorectal and lung cancer), occurring in 50\% of cancers. In some cases, TP53 mutations can be inherited and cause rare forms of hereditary 
neoplastic syndrome. Also, the p53 protein is a target for viral oncogenic proteins coded by SV40, adenoviruses, and HPV. The normal function of TP53 consists of p53 synthesis, which interacts with modified DNA, blocking cell division [11].

Other frequently mutated TSGs are INK4 and PTEN (10q23), correlated with common cancers like lung carcinoma, prostate carcinoma, and melanoma. INK4 codes for a family of cyclin-dependent kinase inhibitors that block CDK4 and CDK6 and are able to arrest the cell in the G1 phase, while PTEN codes for a phosphatase that prevents accelerated growth and overly rapid cell division [11].

\section{Viral oncogenes}

Viral oncogenes can be split into two categories: the ones that determine acute transformation and the ones that lead to a slow transformation. In acute transforming viruses, viral particles contain an overexpressed oncogene, named viral oncogene (v-onc) (Table 3 ). As soon as v-onc is expressed, the cell initiates malignant transformation. Conversely, the genome of the slow transforming viruses is inserted into the host genome in the vicinity of a protooncogene. The viral promoter or other transcription regulatory elements cause the overexpression of said proto-oncogene, which furthermore induces uncontrolled cell proliferation. Because the probability of viral genome insertion in the vicinity of a protooncogene is low, slow transforming viruses have much higher latency for tumor development, as opposed to acute transforming viruses, which already contain the viral oncogene. It is considered that the viral DNA is inserted into the host DNA during transcription or replication, where the two DNA strands are separated [25].

Table 3. Viral oncogenes (based on Zheng et al., 2010 [26]).

\begin{tabular}{c|c|c} 
DNA Virus Family & Examples of viruses & Oncogenes \\
\hline Adenoviridae & Adenovirus 12, 18,31 & E1A, E1B \\
\hline Hepadnaviridae & HBV & HBx \\
\hline Herpesviridae & EBV & LMP-1, BARF-1 \\
& KSHV & E6, E7 \\
\hline Papillomaviridae & HPV 16,18,31, 45 & Oncogenes \\
\hline RNA Virus Family & Examples of viruses & Tax (involved in lymphoma) \\
\hline Retroviridae & T-cell Leukemia virus & Core, E1, E2
\end{tabular}

\subsection{The HPV genome.}

In papillomaviruses, only one of the two DNA strands of the circular molecule is transcribed. Functionally, considering the moment in which they are transcribed during the multiplication cycle, the viral genes are: early (E) - a sequence of $4 \mathrm{~kb}$ that encodes nonstructural proteins; late (L) - a sequence of $\sim 3 \mathrm{~kb}$ that encodes the two capsid proteins; the long control region (LCR) - a sequence of $\sim 1 \mathrm{~kb}$ that contains a variety of in cis-regulatory elements of gene expression (Figure 1) [27].

The insertion of HPV DNA into the host's genome maintains the integrity of LCR and of the encoding regions E6 and E7, but other viral proteins, like the repressor encoded by E2 (an inhibitor of E6/E7 transcription), are inhibited. Consequently, the E6/E7 genes are expressed [28]. Non-isotopic In Situ Hybridization (NISH) studies have shown that, in cervical 
malignant cells, both episomally functional viral genomes and viral genomes integrated into the host genome can coexist [29]. The E6 and E7 genes encode for oncoproteins that induce a high risk of neoplasia. Histogenesis of HPV positive cervical carcinoma cell lines is dependent on the expression of the E6/E7 genes [28]. The key to the multiplication cycle of HPV is maintaining the differentiated keratinocytes in a viable state, accompanied by DNA synthesis [30].

A group of factors that limit the cell division is the $\mathrm{Rb}$ (Retinoblastoma) protein group. These proteins bind a heterodimer consisting of two transcription factors (TF), called E2F-DP. Bound to $\mathrm{Rb}$, these TFs are inactive, but when released, they regulate the expression of genes that prompt the cell to enter S-phase and to initiate DNA replication. For transformation caused by HPV to occur, both the E6 and E7 viral oncoproteins are required. The E7 protein binds to $\mathrm{Rb}$ and inactivates it, releasing E2F-DP and thus, initiating the S-phase and DNA replication of both the host cell and the virus. This phenomenon induces the activation of the tumor suppressor protein $\mathrm{p} 53$, which response to replication stress and, importantly, viral infections, through controlling the expression of various cell cycle genes that in turn, can cause replication senescence, or apoptosis, to avoid abnormal replication rates or replication errors. In order to maintain active its replication cycle, the HPV virus possesses the gene for the E6 oncoprotein, which marks p53 for poly-ubiquitination and then degradation in the proteasome, canceling its tumor-suppressive action. In this way, the virus replicates within the host cell, which, in turn, becomes able to proliferate with an abnormally high rate. Therefore, the cell transformation process is the consequence, not the purpose of the viral activity, which just ensures that viral DNA keeps being replicated by the host cell [30]. E6 and E7 viral oncoproteins modulate host epigenetic mechanisms and histone-modifying enzymes. E7 activates oncogene transcription through its interaction with histone deacetylase. It is also involved in the virus replication cycle and in neoplastic transformation [31].

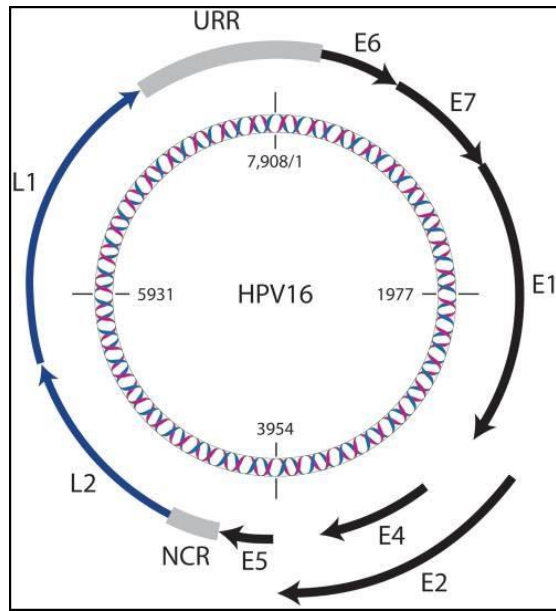

Figure 1. HPV16 genome (by Smith et al., 2011 [32]).

HPV16 E6/E7 can immortalize primary human epithelial cell cultures. The resulting cell lines are not tumorigenic, but oncogenic clones occur in vitro and show chromosomal abnormalities over multiple passages. E6 and E7 proteins from high-risk strains of HPV contribute to this process by inducing genome instability. E6 induces genome instability through p53 inactivation, and E7 disrupts the TSG signaling pathways. Furthermore, E7 proteins from high-risk strains of HPV induce centrosome abnormalities, leading to multipolar mitoses, which represent the hallmark of lesions and cancers associated with high-risk HPV strains [28]. 
As a result of the integration of the viral sequence into the host genome, or as a result of epigenetic changes in the viral genome, uncontrolled expression of HPV E6 and E7 genes bears a high risk of neoplastic cell transformation. Genomic instability induced by E6 and E7 proteins accelerate the proliferation and immortalization of mutant cells. This instability is the most important factor influencing the oncogenic potential of high-risk HPV strains [28].

\section{Oncogenic viruses}

Currently, there are seven viruses known to induce cancer transformations in humans (Table 4). They pose a real threat, especially for people living in developing countries and for immunosuppressed people [3].

Table 4. Principal oncogenic viruses (based on Alberione et al., 2020 [33], Jones et al., 2020 [34], Mui et al., 2017).

\begin{tabular}{|c|c|c|c|c|c|}
\hline Virus & $\begin{array}{c}\text { Viral } \\
\text { Genome }\end{array}$ & Action & Transmission & $\begin{array}{c}\text { Effect on the host } \\
\text { cell }\end{array}$ & Associated cancer \\
\hline $\begin{array}{c}\text { Epstein-Barr } \\
\text { Virus } \\
\text { (HHV-4/EBV) }\end{array}$ & DNA & $\begin{array}{c}\text { non-integrating, a } \\
\text { directly-acting } \\
\text { carcinogen }\end{array}$ & Saliva & $\begin{array}{l}\text {-accelerated } \\
\text { proliferation } \\
\text {-inhibits DNA } \\
\text { repair }\end{array}$ & $\begin{array}{c}\text { Burkitt's lymphoma, } \\
\text { Hodgkin lymphoma, } \\
\text { Naso } \\
\text { pharyngeal and gastric } \\
\text { cancer }\end{array}$ \\
\hline $\begin{array}{c}\text { Kaposi's } \\
\text { Sarcoma- } \\
\text { associated Herpes } \\
\text { virus } \\
(\text { HHV-8) } \\
\end{array}$ & DNA & $\begin{array}{c}\text { non-integrating, a } \\
\text { directly-acting } \\
\text { carcinogen }\end{array}$ & $\begin{array}{l}\text { saliva, blood, } \\
\text { sexually; rarely } \\
\text { from mother to } \\
\text { fetus }\end{array}$ & $\begin{array}{l}\text {-accelerated } \\
\text { proliferation } \\
\text { - inhibits DNA } \\
\text { repair }\end{array}$ & $\begin{array}{c}\text { Kaposi's sarcoma } \\
\text { (common in HIV } \\
\text { infected individuals) }\end{array}$ \\
\hline $\begin{array}{l}\text { Merkel Cell } \\
\text { Polyoma } \\
\text { virus (PCMyV) }\end{array}$ & DNA & $\begin{array}{l}\text { non-integrating, an } \\
\text { indirectly-acting } \\
\text { carcinogen }\end{array}$ & $\begin{array}{l}\text { Unknown } \\
\text { (probably, } \\
\text { cutaneous, } \\
\text { respiratory, } \\
\text { gastrointestinal) }\end{array}$ & -inhibits p53 gene & Merkel cell carcinoma \\
\hline $\begin{array}{c}\text { Human Papilloma } \\
\text { Virus (HPV) }\end{array}$ & DNA & $\begin{array}{l}\text { integrating (cervical } \\
\text { cancer)/mainly non- } \\
\text { integrating, a } \\
\text { directly-acting } \\
\text { carcinogen }\end{array}$ & $\begin{array}{c}\text { cutaneous/ } \\
\text { mucosal direct } \\
\text { contact }\end{array}$ & $\begin{array}{l}\text {-cell cycle } \\
\text { deregulation }\end{array}$ & $\begin{array}{c}\text { cervical, penile, vulvar, } \\
\text { vaginal, anal, oro } \\
\text { pharyngeal carcinomas }\end{array}$ \\
\hline $\begin{array}{c}\text { Hepatitis B Virus } \\
(\mathrm{HBV})\end{array}$ & DNA & $\begin{array}{l}\text { integrating ( } 80- \\
90 \%) \text {, directly/ } \\
\text { indirectly-acting } \\
\text { carcinogen }\end{array}$ & $\begin{array}{l}\text {-percutaneous/ } \\
\text { mucosal contact } \\
\text {-secretions from } \\
\text { an infected } \\
\text { individual }\end{array}$ & $\begin{array}{c}\text {-cell cycle } \\
\text { deregulation } \\
\text { - oxidative stress } \\
\text { resistance } \\
\text {-indirect- chronic } \\
\text { inflammation }\end{array}$ & $\begin{array}{c}\text { Hepato } \\
\text { cellular carcinoma }\end{array}$ \\
\hline $\begin{array}{c}\text { Hepatitis C Virus } \\
(\mathrm{HCV})\end{array}$ & RNA & $\begin{array}{l}\text { Rarely integrating, } \\
\text { indirectly/ } \\
\text { directly-acting } \\
\text { carcinogen }\end{array}$ & $\begin{array}{l}\text {-percutaneous/ } \\
\text { mucosal contact } \\
\text {-secretions from } \\
\text { an infected } \\
\text { individual }\end{array}$ & $\begin{array}{c}\text { - cell cycle } \\
\text { deregulation } \\
\text { - oxidative stress } \\
\text { resistance } \\
\text { - indirect - chronic } \\
\text { inflammation }\end{array}$ & $\begin{array}{c}\text { Hepato } \\
\text { cellular carcinoma }\end{array}$ \\
\hline $\begin{array}{l}\text { Human T-lympho } \\
\text { tropic virus } \\
\text { (HTLV-1) }\end{array}$ & RNA & $\begin{array}{l}\text { integrating, a } \\
\text { directly-acting } \\
\text { carcinogen }\end{array}$ & $\begin{array}{l}\text { infected maternal } \\
\text { milk, sexually, } \\
\text { blood }\end{array}$ & $\begin{array}{l}\text {-cell cycle } \\
\text { deregulation } \\
\text {-inhibits DNA } \\
\text { repair -cellular } \\
\text { oncogene } \\
\text { activation }\end{array}$ & $\begin{array}{c}\text { Angio } \\
\text { immuno } \\
\text { blastic T-Cell } \\
\text { Lymphoma }\end{array}$ \\
\hline
\end{tabular}

\subsection{Human papilloma virus (HPV).}

Using DNA sequencing, over 200 strains of HPV were identified. These were grouped into 5 subfamilies: $\alpha, \beta, \gamma, v$ and $\mu$. The viral strains included in the $\alpha$ subfamily infect the mucosa, whereas the ones from $\beta$ and $\gamma$ infect the skin. HPVs are classified into 2 categories of risk for neoplasia: low-risk (LR) and high-risk (HR). High-risk strains are included in the $\alpha$ 
subfamily, the most common strains being HPV16, HPV18, HPV31, HPV33, HPV52, and HPV58. The most common low-risk strains are HPV6, HPV11, and HPV53 [35,3].

\section{Major neoplasms caused by cellular oncogenes}

Of the total cancer cases in the world, lung cancer, as well as breast cancer, represent 12,3\%. They are followed by colorectal cancer, with 10,6\%, prostate cancer, with 7,5\%, stomach cancer, with $6,1 \%$, while esophageal cancer represents $3,4 \%$ [36].

\subsection{Lung cancer.}

Lung cancer is the leading cause of cancer death among both men and women. Pulmonary neoplasms are invasive and metastatic [37], and they can be detected only in the late stages when the symptoms become obvious. Most types of lung cancer are carcinomas, developing from epithelial cells [38]. There are two main histological subtypes of lung cancer: Small cell lung cancers (SCLC), characterized by the presence of neurosecretory granules; Non-small cell lung cancers (NSCLC) or squamous cell carcinomas [39].

The primary tumor is associated with thoracic discomfort, cough, hemoptysis, dyspnea, and it develops until the invasion of the chest wall, followed by extrathoracic metastasis during the final stage [40].

The major risk factors for lung cancer: Smoking (responsible for $85 \%$ of lung cancer cases) and passive smoking (responsible for 10-15\% of cancer cases); smokers are 10 to 30 times more likely to develop lung cancer than non-smokers [41]; Asbestos exposure (the fibrous form of some natural minerals): microscopic fibers can be released from asbestos minerals that can subsequently be deposited in alveolar macrophages; Radon, Arsenic, Nickel, or Chromium exposure; Air pollution caused by sulfur aerosols or nitrogen dioxide; Exposure to ionizing radiation [42].

However, genetic predisposition is responsible for $8 \%$ - $14 \%$ of global lung cancer cases. Very importantly, the presence of non-cancerous lung diseases such as Chronic obstructive pulmonary disease, Idiopathic pulmonary fibrosis, or Tuberculosis is associated with an increased risk in developing lung cancer [43].

\section{Neoplasms caused by viral oncogenes}

Approximately $10 \%$ to $20 \%$ of all types of cancer can be attributed to viral infections. There are seven human viruses known for their ability to initiate the process of carcinogenesis [44]: HPV (Human Papilloma Virus) - cervical cancer, penile cancer, vulvar cancer, vaginal cancer, anal cancer, and oropharyngeal cancer; hepatitis B and hepatitis C viruses hepatocellular carcinoma; Merkel cell polyomavirus - Merkel cell carcinoma; Epstein-Barr virus (HHV-4) - Burkitt lymphoma, Hodgkin lymphoma, nasopharyngeal carcinoma, stomach cancer; Kaposi's sarcoma-associated herpesvirus (HHV-8) - Kaposi's sarcoma (the most common among HIV patients); human T-lymphotropic virus (HTLV-1) - angioimmunoblastic T-cell lymphoma [44,3]. 


\subsection{Cervical cancer.}

Cervical cancer is the fourth most common type of cancer in women and also the fourth most common cause of death from cancer in the world, with 530.000 new cases and 270.000 deaths occurring annually [45].

HPV infection represents the major risk factor (it is responsible for over $90 \%$ of all cases), but there are other risk factors, including the early debut of sexual activity, multiple sexual partners, the number of abortions, inappropriate contraceptive methods, smoking, low socioeconomic status, diet, and the patient's history with regard to other sexually transmitted infections [46].

Human Papilloma Virus infections usually occur in young women between ages 18 to 30. Despite this, cervical cancer is less common before the age of 35 . The interval between exposure and neoplastic onset suggests that the evolution of the neoplastic process is slow. However, the time required for malignant transformation and for the microtumor to reach a clinical-stage remains unknown [47].

The most common types of cervical cancer are squamous cell carcinoma (69\% of cases) and adenocarcinoma (25\% of cases). HPV infections are found in 59,3\% of squamous cell carcinoma cases, and in 36,3\% of adenocarcinoma cases [47].

About $10 \%$ of women with normal cervical cytology have HPV infections. Despite this, many of them will not develop abnormal cytology because most HPV cervical infections are eradicated in 6 to 18 months. The most common symptoms are vaginal bleeding, bleeding during sexual intercourse, pain during sexual intercourse [46].

The transformation zone between the columnar epithelium of the endocervix (which lines the endocervical canal and endocervical crypts) and the squamous epithelium of the ectocervix represents the most common site for persistent HPV infection, cervical intraepithelial neoplasia, and even for cervical cancer. The development of cervical cancer is a multistep process: HPV infection of the transformation zone, host failure to eliminate the virus, development of cervical intraepithelial neoplasia, and invasion of the epithelial basement membrane [47].

\subsection{Secondary pathologies associated with oncogenic viruses.}

- HPV: Plantar warts; Common warts (rough keratotic excrescences, located on the surface of the hands, palms, fingers and around the nails); Filiform warts or papillomas (pink excrescences, located on the scalp, face, and neck); Flat warts (small papules on the face, hands, and calves); Condylomas (fleshy, formless excrescences, located in the genital and inguinal areas);

- hepatitis B virus: hepatitis B;

- hepatitis $\mathrm{C}$ virus: hepatitis $\mathrm{C}$;

- Epstein-Barr virus: Infectious mononucleosis [3].

\section{Evolution of viral oncogenes}

One possible explanation for the sequence similarity between viral oncogenes and cellular oncogenes can be the strategy of the retrovirus for spread and survival. The virus inserts its genetic material into the genome of the host cell for replication. To infect other cells, the viral genome is excised from the host cell, sometimes along with small regions of the host's 
genome. If this imperfect excision results in the integration of a proto-oncogene into the genetic material of the virus, then the proto-oncogene will not benefit from regulation, given the limited genetic apparatus of the retrovirus. Thus, the proto-oncogene becomes a viral oncogene. When the viral oncogene infects another cell, the enzyme called reverse transcriptase generates cDNA, which is then integrated into the cell genome (Figure 2) [4].

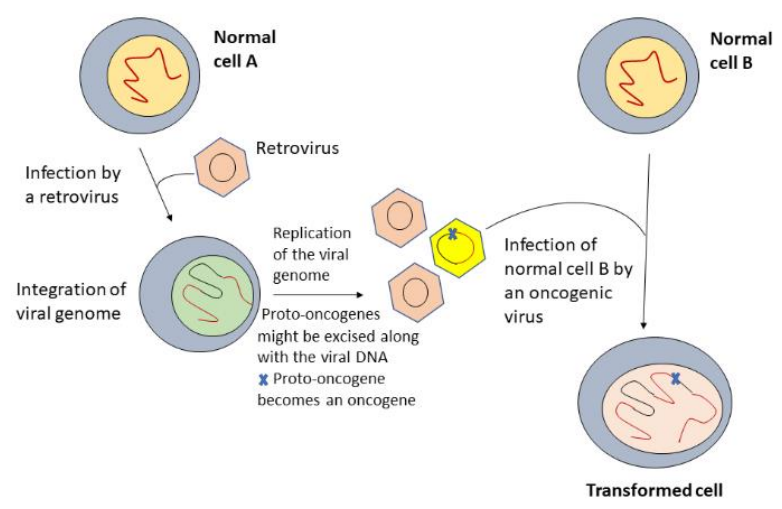

Figure 2. Mechanism of oncogene acquirement by retroviruses.

As shown in Table 5, viral and cellular oncogenes seem to share multiple similarities, as viral oncogenes are proven to have chimeric gene structures, probably due to fusions with cellular DNA [4].

Table 5. Comparison between viral oncogenes and cellular oncogenes (based on Encyclopædia Britannica, 2019; Sharma et al., 2010; Sondka et al., 2018; Zandi et al., 2007; Zheng, 2010; zur Hausen, 1991).

\begin{tabular}{c|c|c} 
Oncogenes & Viral & Cellular \\
\hline Origin & $\begin{array}{c}\text { Viral; possibly, stolen from } \\
\text { previously infected cells }\end{array}$ & Cellular \\
\hline Diversity & Low (tens) & High (hundreds) \\
\hline Activation & Integrative or episomal & $\begin{array}{c}\text { Mutations/epigenetic alterations of } \\
\text { proto-oncogenes }\end{array}$ \\
\hline Epigenetic control & Modified post-integration & Very tight \\
\hline Mechanism of tumorigenesis & $\begin{array}{c}\text { Direct alteration of the cell } \\
\text { cycle/activation of } \\
\text { proto-oncogenes }\end{array}$ & $\begin{array}{c}\text { Direct alteration } \\
\text { of the cell cycle }\end{array}$
\end{tabular}

\section{Conclusions}

Different types of cancer can be the result of both epigenetic alteration and intracellular or extracellular mutagenic factors. However, studies show that any cancer case always involves the aberrant activity of cellular oncogenes, viral oncogenes, or tumor suppressor genes.

Comparative analysis of the two types of oncogenes showed high structural and functional similarity between them. Viral oncogenes can lead to direct alteration of the cell cycle and uncontrolled proliferation through mechanisms similar to those found in overexpressed proto-oncogenes. Nevertheless, sometimes, viral oncogenes can activate protooncogenes from the genome of the infected host cell.

Proto-oncogenes and tumor suppressor genes are under tight epigenetic control, which provides the correct progression of the cell cycle. Similar epigenetic modifications have been described in viral oncogenes, but in this case, they mask the viral genome in order not to generate a cell-mediated immune response and in order to maintain an intense level of gene transcription. 
All these similarities between cellular oncogenes and viral oncogenes, as well as the information in the literature, support the hypothesis that viral oncogenes originated from protooncogenes that were part of the host's genome. Proto-oncogenes were integrated into the viral genome, and they are now expressed as oncogenes, given the limited regulatory genetic apparatus of the virus.

\section{Funding}

This research received no external funding.

\section{Acknowledgments}

We would like to thank Conf. Dr. Dănuț Gheorghe Cimponeriu, from the Department of Genetics, Faculty of Biology, University of Bucharest, for his valuable feedback and for his advice on publishing this work.

\section{Conflicts of Interest}

The authors declare no conflict of interest.

\section{References}

1. Kumar, V.; Abbas, A.K.; Fausto, N.; Mitchell, R.N. Robbins Basic Pathology. 8th edition, Saunders/Elsevier: Philadelphia (PA), US, 2007.

2. Pappou, E.P; Ahuja, N. The Role of Oncogenes in Gastrointestinal Cancer. Gastrointest Cancer Res. 2010, $1, \mathrm{~S} 2-\mathrm{S} 15$.

3. Mui, U.N.; Haley, C.T.; Tyring, S.K. Viral Oncology: Molecular Biology and Pathogenesis. Journal of Clinical Medicine 2017, 6, 111-168, https://doi.org/10.3390/jcm6120111.

4. Oncogene. Encyclopædia Britannica. Available online: https://www.britannica.com/science/oncogene (accessed on 22.04.2019).

5. Adamson, E.D. Oncogenes in development. Development (Cambridge, England) 1987, 99, 449-471.

6. Weinstein, I.B.; Joe, A.K. Mechanisms of disease: Oncogene addiction-a rationale for molecular targeting in cancer therapy. Nature Clinical Practice Oncology. 2006, 3, 448-457, https://doi.org/10.1038/ncponc0558.

7. Chial, H. Proto-oncogenes to oncogenes to cancer. Nature Education 2008, 1.

8. Anania, M. C.; Di Marco, T.; Mazzoni, M.; Greco, A. Targeting Non-Oncogene Addiction: Focus on Thyroid Cancer. Cancers. 2020, 12(1), 129. https://doi.org/10.3390/cancers12010129.

9. Zacharias, F.; George, D.; Michail, D.; Ioannis, P.; Marianna, T.; Arzou, B.; Dimitra, A.; Athanasios, P.; Emmanuel, K. N. MicroRNAs Determining Carcinogenesis by Regulating Oncogenes and Tumor Suppressor Genes During Cell Cycle. MicroRNA (Shariqah, United Arab Emirates). 2020, 9(2), 82-92. https://doi.org/10.2174/2211536608666190919161849.

10. Makela, T.P.; Mattson, K.; Alitalo, K. Tumour Markers and Oncogenes in Lung Cancer. European Journal of Cancer 1991, 27, 1323-1327, https://doi.org/10.1016/0277-5379(91)90106-N.

11. Cooper, G.M. Oncogenes. In: The Cell: A Molecular Approach. 2nd ed; Sinauer Associates, Sunderland (MA), USA, 2000.

12. Chandrashekar, P.; Ahmadinejad, N.; Wang, J.; Sekulic, A.; Egan, J.B.; Asmann, Y.W.; Kumar, S.; Maley, C.; Liu, L. Somatic selection distinguishes oncogenes and tumor suppressor genes. Bioinformatics. 2020, 36(6), 1712-1717. https://doi.org/10.1093/bioinformatics/btz851.

13. Sondka, Z.; Bamford, S.; Cole, C.G.; Ward, S.A.; Dunham, I.; Forbes, S.A. The COSMIC Cancer Gene Census: describing genetic dysfunction across all human cancers. Nature Reviews Cancer 2018, 18, 696705, https://doi.org/10.1038/s41568-018-0060-1.

14. Futreal, P.A.; Coin, L.; Marshall, M.; Down, T.; Hubbard, T.; Wooster, R.; Rahman, N.; Stratton, M.R. A census of human cancer genes. Nature Reviews Cancer 2004, 4, 177-183, https://doi.org/10.1038/nrc1299.

15. Primo, L.M.F.; Teixeira, L.K. DNA replication stress: oncogenes in the spotlight. Genet. Mol. Biol. 2020, 43(1 Suppl 1): e20190138. http://dx.doi.org/10.1590/1678-4685-gmb-2019-0138.

16. Nandi, B.; Talluri, S.; Kumar, S.; Yenumula, C.; Gold, J.S.; Prabhala, R.; Shammas, M.A. The roles of homologous recombination and the immune system in the genomic evolution of cancer. J. Transl. Sci. 2008, 5, 1-15, https://doi.org/10.15761/JTS.1000282. 
17. Sharma, S.; Kelly, T.K.; Jones, P.A. Epigenetics in cancer. Carcinogenesis 2010, 31, 27-36, https://doi.org/10.1093/carcin/bgp220.

18. Jang, H.S.; Shah, N.M.; Du, A.Y.; Dailey, Z.Z.; Pehrsson, E.C.; Godoy, P.M.; Zhang, D.; Li, D.; Xing, X.; Kim, S.; O’Donnell, D.; Gordon, J.I.; Wang, T. Transposable elements drive widespread expression of oncogenes in human cancers. Nat Genet. 2019, 51, 611-617. https://doi.org/10.1038/s41588-019-0373-3.

19. NIH: National Institutes of Health. Available online: https://ghr.nlm.nih.gov/condition/lungcancer\#resources (accessed on 22.04.2019).

20. Konstantinidou, G; Rimessi, A. Editorial: Oncogenic RAS-Dependent Reprogramming of Cellular Plasticity. Frontiers in Oncology. 2020, 10, 588. https://doi.org/10.3389/fonc.2020.00588.

21. Zandi, R.; Larsen, A.B.; Andersen, P.; Stockhausen, M.-T.; Poulsen, H.S. Mechanisms for oncogenic activation of the epidermal growth factor receptor. Cellular Signalling 2007, 19, 2013-2023, https://doi.org/10.1016/j.cellsig.2007.06.023.

22. Clayton, E. A.; Khalid, S.; Ban, D.; Wang, L.; Jordan, I. K.; McDonald, J. F. Tumor suppressor genes and allele-specific expression: mechanisms and significance. Oncotarget. 2020, 11(4), 462-479. https://doi.org/10.18632/oncotarget.27468.

23. Knudson, A.G. Mutation and Cancer: Statistical Study of Retinoblastoma. 1971, 68, 820-823, https://doi.org/10.1073/pnas.68.4.820.

24. Fang, Y.; Tsao, C.-C.; Goodman, B.K.; Furumai, R.; Tirado, C.A.; Abraham, R.T.; Wang, X.-F. ATR functions as a gene dosage-dependent tumor suppressor on a mismatch repair-deficient background. The EMBO Journal 2004, 23, 3164-3174, https://doi.org/10.1038/sj.emboj.7600315.

25. zur Hausen, H. Viruses in human cancers. Science 1991, 254, 1167-1173, https://doi.org/10.1126/science.1659743.

26. Zheng, Z.-M. Viral Oncogenes, Noncoding RNAs, and RNA Splicing in Human Tumor Viruses. International Journal of Biological Sciences 2010, 6, 730-755, https://doi.org/10.7150/ijbs.6.730.

27. Münger, K.; Baldwin, A.; Edwards, K.M.; Hayakawa, H.; Nguyen, C.L.; Owens, M.; Grace, M.; Huh, K. Mechanisms of Human Papillomavirus-Induced Oncogenesis. J Virol 2004, 78, 11451-11460, https://doi.org/10.1128/JVI.78.21.11451-11460.2004.

28. Mesri, Enrique A.; Feitelson, M.A.; Munger, K. Human Viral Oncogenesis: A Cancer Hallmarks Analysis. Cell Host \& Microbe 2014, 15, 266-282, https://doi.org/10.1016/j.chom.2014.02.011.

29. Cooper, K.; Herrington, C.S.; Stickland, J.E.; Evans, M.F.; McGee, J.O. Episomal and integrated human papillomavirus in cervical neoplasia shown by non-isotopic in situ hybridisation. Journal of Clinical Pathology 1991, 44, 990-996, http://dx.doi.org/10.1136/jcp.44.12.990.

30. Levine, A.J. The common mechanisms of transformation by the small DNA tumor viruses: The inactivation of tumor suppressor gene products: p53. Virology 2009, 384, 285-293, https://doi.org/10.1016/j.virol.2008.09.034.

31. Soto, D.; Song, C.; McLaughlin-Drubin, M.E. Epigenetic Alterations in Human Papillomavirus-Associated Cancers. Viruses 2017, 9, 248-265, https://doi.org/10.3390/v9090248.

32. Smith, B.; Chen, Z.; Reimers, L.; van Doorslaer, K.; Schiffman, M.; Desalle, R.; Herrero, R.; Yu, K.; Wacholder, S.; Wang, T.; Burk, R.D. Sequence imputation of HPV16 genomes for genetic association studies. PLOS ONE. 2011, 6, 21375, https://doi.org/10.1371/journal.pone.0021375.

33. Alberione, M.P.; Moeller, R.; Kirui, J.; Ginkel, C.; Doepke, M.; Ströh, L.J.; Machtens, J.P.; Pietschmann, T.; Gerold, G. Single nucleotide variants in human CD81 infuence hepatitis C virus infection of hepatoma cells. Medical Microbiology and Immunology. 2020, 209, 499-514. https://doi.org/10.1007/s00430-02000675-1.

34. Jones, J. M.; Kracalik, I.; Levi, M. E.; Bowman, J. S.; 3rd, Berger, J. J.; Bixler, D.; Buchacz, K.; Moorman, A.; Brooks, J. T.; Basavaraju, S. V. Assessing Solid Organ Donors and Monitoring Transplant Recipients for Human Immunodeficiency Virus, Hepatitis B Virus, and Hepatitis C Virus Infection - U.S. Public Health Service Guideline, 2020. Morbidity and mortality weekly report. Recommendations and reports. 2020, 69(4), 1-16. https://doi.org/10.15585/mmwr.rr6904a1.

35. Kann, H.; Hortlund, M.; Eklund, C.; Dillner, J.; Faust, H. Human papillomavirus types in cervical dysplasia among young HPV-vaccinated women: Population-based nested case-control study. International Journal of Cancer. 2020, 146(9), 2539-2546. https://doi.org/10.1002/ijc.32848.

36. Hashim, D.; Boffetta, P.; La Vecchia, C.; Rota, M.; Bertuccio, P.; Malvezzi, M.; Negri, E. The global decrease in cancer mortality: trends and disparities. Annals of Oncology 2016, 27, 926-933, https://doi.org/10.1093/annonc/mdw027.

37. Altorki, N.K.; Markowitz, G.J.; Gao, D.; Port, J.L.; Saxena, A.; Stiles, B.; McGraw, T.; Mittal, V. The lung microenvironment: an important regulator of tumour growth and metastasis. Nature Reviews Cancer 2019, 19, 9-31, https://doi.org/10.1038/s41568-018-0081-9.

38. Vaporciyan, A.A.; Nesbitt, J.C.; Lee, J.; Stevens, C.; Komaki, R.; Roth, J.A. Cancer of the lung. In: HollandFrei Cancer Medicine. 6th ed; Kufe, D.W.; Pollock, R.E.; Weichselbaum, R.R.; Bast, R.C.; Gansler, T.S.; Holland, J.F.; Frei, E. Eds.; BC Decker, Hamilton (ON), Canada, Volume 5, 2003. 
39. Vincent, R.G.; Pickren, J.W.; Lane, W.W.; Bross, I.; Takita, H.; Houten, L.; Gutierrez, A.C.; Rzepka, T. The changing histopathology of lung cancer. A review of 1682 cases. Cancer 1977, 39, 1647-1655, https://doi.org/10.1002/1097-0142(197704)39:4<1647::AID-CNCR2820390439>3.0.CO;2-H.

40. Beckles, M.A.; Spiro, S.G.; Colice, G.L.; Rudd, R.M. Initial evaluation of the patient with lung cancer: symptoms, signs, laboratory tests, and paraneoplastic syndromes. Chest. 2003, 123, 97-104, https://doi.org/10.1378/chest.123.1_suppl.97S.

41. Hecht, S.S. Lung carcinogenesis by tobacco smoke. International Journal of Cancer 2012, 131, 2724-2732, https://doi.org/10.1002/ijc.27816.

42. Richard, W.C.; Molly, M.J.; Edward, L.L. Environmental and Occupational Causes of Cancer: New Evidence 2005-2007. Reviews on environmental health 2008, 23, 1-38, https://doi.org/10.1515/REVEH.2008.23.1.1.

43. Travis, W.D. Pathology of lung cancer. Clin Chest Med. 2002, 23, 65-81, https://doi.org/10.1016/j.ccm.2011.08.005.

44. Boudreault, S.; Tremblay, M.P.; Allaire, A.; Armero, V.E.S.; Bisaillon, M. Viral oncoproteins involved in carcinogenesis. Virology. 2016, 13, 69-86, https://doi.org/10.3390/cancers6042155.

45. Forman, D.; de Martel, C.; Lacey, C.J.; Soerjomataram, I.; Lortet-Tieulent, J.; Bruni, L.; Vignat, J.; Ferlay, J.; Bray, F.; Plummer, M.; Franceschi, S. Global Burden of Human Papillomavirus and Related Diseases. Vaccine 2012, 30, F12-F23, https://doi.org/10.1016/j.vaccine.2012.07.055.

46. Schiffman, M.; Castle, P.E.; Jeronimo, J.; Rodriguez, A.C.; Wacholder, S. Human papillomavirus and cervical cancer. The Lancet 2007, 370, 890-907, https://doi.org/10.1016/S0140-6736(07)61416-0.

47. Burd, E.M. Human Papillomavirus and Cervical Cancer. Clinical Microbiology Reviews 2003, 16, 1-17, https://doi.org/10.1128/CMR.16.1.1-17.2003. 